\title{
NEAR-FIELD TSUNAMI HAZARD MAP PADANG, WEST SUMATRA: UTILIZING HIGH RESOLUTION GEOSPATIAL DATA AND RESEASONABLE SOURCE SCENARIOS
}

\author{
T. Schlurmann', W. Kongko' ${ }^{1}$ N. Goseberg ${ }^{1}$, D. H. Natawidjaja ${ }^{2}$ and K. Sieh ${ }^{3}$
}

Near-field tsunami propagation both in shallow water environments and bore-like wave propagation on land are conducted in this study to obtain fundamental knowledge on the tsunami hazard potential in the city of Padang, Western Sumatra, Republic of Indonesia. As the region proves a huge seismic moment deficit which has progressively accumulated since the last recorded major earthquakes in 1797 and 1833, this investigation focuses on most reasonable seismic sources and possibly triggered nearshore tsunamis in order to develop upgraded disaster mitigations programs in this densely-populated urban agglomeration located on the western shore of Sumatra Island. Observations from continuous Global Positioning Satellite (cGPS) systems and supplementary coral growth studies confirm a much greater probability of occurrence that a major earthquake and subsequent tsunami are likely to strike the region in the near future. Newly surveyed and processed sets of geodata have been collected and used to progress most plausible rupture scenarios to approximate the extent and magnitudes of a further earthquake. Based upon this novel understanding, the present analysis applies two hydronumerical codes to simulate most probable tsunami run-up and subsequent inundations in the city of Padang in very fine resolution. Run-up heights and flow-depths are determined stemming from these most plausible rupture scenarios. Evaluation of outcome and performance of both numerical tools regarding impacts of surge flow and bore-like wave fronts encountering the coast and inundating the city are thoroughly carried out. Results are discussed not only for further scientific purposes, i.e. benchmark tests, but also to disseminate main findings to responsible authorities in Padang with the objective to distribute the most probable dataset of plausible tsunami inundations as well as to address valuable insights and knowledge for effective counter measures, i.e. evacuation routes and shelter building. Following evacuation simulations based on rational assumptions and simplifications reveal a most alerting result as about 265.000 people are living in the highly exposed potential tsunami inundation area in the city of Padang of which more than 95.000 people will need more than $30 \mathrm{~min}$. to evacuate to safe areas.

Keywords: tsunami hazard modeling; risk assessment; $2 D$ nonlinear shallow water equations; coastal development; integrated coastal zone management, disaster risk reduction

\section{BACKGROUND AND MOTIVATION}

Tsunamis are one of the largest and most devastating naturally created geophysical extreme hazards which put countless coastal stretches worldwide at risk. The great Sumatra-Andaman earthquake and succeeding tsunami of December 2004 caused disastrous property damage and loss of life. It underscored the importance of understanding and studying the inherent seismic and tsunami hazards of subduction zones and to progress the development of sensor networks and foster public policy to realize global end-to-end tsunami early warning systems (Bernard et al. 2006). Achieving this aspired goal requires forging a chain linking basic science to people's everyday lives as Sieh (2006) clarifies. The intermediate links in this chain are emergency response preparedness, warning capability, education and infrastructural changes. In this regard Lauterjung et al. (2010) provide an unmistakable picture on the challenge of establishing a tsunami early warning system in the vicinity of the Sunda Arc in the Republic of Indonesia making an effort to address and integrate the links in this chain.

\section{Structure of paper}

This paper is organized as follows. After an elaborate picture of the main background and motivation of this research is given, the following part covers the acquisition and processing of newly surveyed sets of geodata and used to progress most plausible rupture scenarios to advance knowledge about further great earthquake and subsequently triggered tsunamis in the region off the Mentawai Islands. This paragraph is followed by an in-depth analysis of the two applied numerical codes established on the 2D nonlinear shallow water equations to simulate most probable tsunami run-up an inundations near-shore and in the city of Padang in very fine resolutions. The final paragraph discusses the outcome of the study and further delineates the demands for dissemination and communication of the main findings, i.e. give explanation of the results to responsible authorities in Padang in order to derive valuable insights and knowledge for effective counter measures like evacuation routes and consequent shelter building as well as in the mid-term perspective to foster development of integrated coastal zone management strategies.

${ }^{1}$ Franzius-Institute for Hydraulic, Waterways and Coastal Engineering, Leibniz Universität Hannover, Nienburgerstraße 4, Hannover, 30167, Germany, Email: schlurmann@fi.uni-hannover.de

${ }^{2}$ LabEarth - Research Center Geotechnology, Indonesian Institute of Sciences (LIPI), Road Sangkuriang, 40135 Bandung, Republic of Indonesia, Email: danny.hilman@gmail.com

${ }^{3}$ Earth Observatory of Singapore (EOS), Nanyang Technological University (NTU), 50 Nanyang Avenue, Singapore 639798, Email: sieh@ntu.edu.sg 
Characteristics of the Sumatran megathrust

What is known today is that the Sumatran megathrust has failed considerably in March 2005 and September 2007, leaving the segment along the northern Mentawai islands relatively intact. Accordingly, various authors draw attention to the substantial tsunami hazard potential in the Indonesian densely-populated urban agglomeration, the city of Padang, with about 850.000 inhabitants located on the western shore of Sumatra (Borrero et al. 2006, McCaffrey 2007, McCloskey et al. 2007, Okal and Synolakis 2008); see also Fig. 1 for an overview of the location and its key coastal landmarks. It is widely acknowledged that the region of the Mentawai Islands and in adjacent areas proves a huge seismic moment deficit which has progressively accumulated since the last recorded major earthquakes in 1797 and 1833 (McCloskey et al. 2008). In the Sumatra area the plates meet in a subduction zone, where the boundaries of the Indian plate are forced beneath the Australian plate. The plates are sliding northeastward at about $7 \mathrm{~cm}$ per year and dipping under the Sunda plate, which encompasses Sumatra and Singapore.

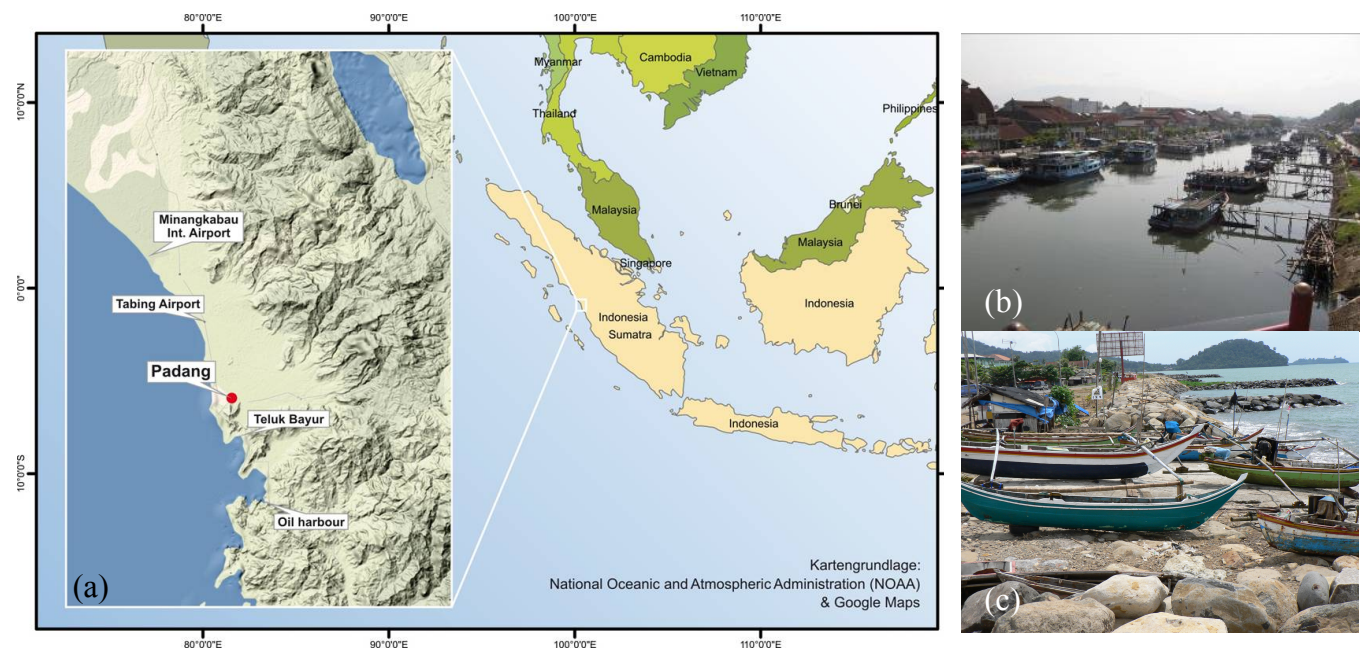

Figure 1. Location of the city of Padang, Western Sumatra, Republic of Indonesia (a), panorama view of the net of urban waterways and drainage canals (b), and typical shoreline setting with seawall and groin field (background) as main components of the coastal defense system preventing coastal erosion (c).

The Sunda megathrust is the fault line along which the plates join, with the upper rocks thrusting upward in a gentle slope above the lower rocks. Until these specific subducting oceanic plates drop deeper into the earth to about $30 \mathrm{~km}$ beneath Sumatra, the megathrust resists slippage and the edges of the plates become coupled, i.e. seismically locked, so that strain built up since the last major earthquake about two centuries ago. Up-to-date, the major earthquake in 1833 is recognized as the renowned worst-case, but realistic and historically proven, scenario for any numerical simulation of the near- and far-field effects of tsunamis generated from potential future earthquakes in the particular area.

In this framework, Borrero et al. (2009) concentrate on the 2007 September $12 \mathrm{Mw}=8.4$, earthquake, off the shores of the Bengkulu province, South Sumatra, Indonesia. They carefully investigate the tsunami triggered by the earthquake with run-up heights of up to $4 \mathrm{~m}$ along the adjacent coastlines in the region of which the largest wave heights and most severe inundation were recorded about $50 \mathrm{~km}$ to the northwest of Bengkulu, a major city located approximately $400 \mathrm{~km}$ south-east of the city of Padang. Moreover, it is accepted that the Sunda megathrust is well advanced in its seismic cycle and may be ready for another large earthquake in consequence of a series of major earthquakes in the late $1300 \mathrm{~s}$, in about 1600 and again in the early 1800s. The latest cluster of Sumatran earthquakes over the past decade is part of a new cycle with a return period of about 200 years that will probably be completed within the next several decades with the occurrence of another major earthquake caused by the failure of an as yet unruptured section of the Sunda megathrust. In this respect, McCloskey et al. (2009) analyze the 30 September 2009 earthquake with a moment magnitude of $\mathrm{Mw}=7.6$ in close proximity of the city of Padang which caused approximately 1200 casualties and severe infrastructural damages. Despite its rather strong magnitude the quake appears to have been produced by the rupture of a fault within the descending plate, well below the megathrust in roughly $80 \mathrm{~km}$ depth. Due to that 
reason no significant tsunami was triggered. The 30 September 2009 earthquake was the latest in a series of five major quakes that affected the region in the period of the last five years. Hitherto, McCloskey et al. conclude from seismic records and subsequent calculations that this particular 30 September 2009 event did not rupture the Sunda megathrust, so that it insignificantly relaxed the accumulated stress on the Mentawai segment and that the megathrust strain-energy budget remains substantially unchanged. They argue that the imposed threat of an earthquake on the Mentawai patch is unabated and expected to rupture the region within the next decades generating a possibly devastating earthquake followed by a triggered massive tsunami that is most likely to strike nearby cities and numerous smaller coastal towns along the shores of West Sumatra. In their summary McCloskey et al. (2009) point out that given the tragic loss of life resulting from the September 2009 Padang earthquake, the threat from such an event is clear and the need for urgent mitigating action remains extremely high.

Given that background and well in advance of recent disastrous earthquakes in the region and activities to develop counter measures in Padang, a group of scientists in early 2007 started a scientific collaboration in the framework of the special program "Geotechnologies - Early Warning Systems in Earth Management" funded by the German Government to develop a so-called numerical last mile tsunami early warning and evacuation information system on the basis of detailed earth observation data and techniques as well as unsteady, hydraulic numerical modeling of small-scale flooding and inundation dynamics of the tsunami including evacuation simulations in the urban coastal hinterland for the city of Padang (Birkmann et al 2008a, Birkmann et al. 2008b and Taubenboeck et al. 2009). Since then the project has been developed in close cooperation with the local authorities and colleagues from Andalas University in Padang as well as the Indonesian research institutions.

By means of modeling tsunami inundation scenarios and simulations of evacuation processes crucial elements of disaster preparedness strategies have been developed and made available. Furthermore, by creating and implementing a suitable software application, i.e. a tsunami information system, key elements of a decision support system (DSS) to review disaster mitigation strategies are created. This DSS can be used to help structuring and managing drills and other preparedness activities in advance of any future natural disaster. On the whole the project was set up to progress advancement of knowledge and insight about the detailed flow dynamics of tsunamis as well as was intended to pinpoint to optimized early warning and evacuation mechanisms in the city of Padang which at the same time finds operation into municipal processes and spatial planning efforts in an attempt to deal with an integrated coastal zone management in Padang. But what is more is that up-to-date risk perception and public awareness on a very local level based on state-of-the-art geodata basis and meticulous scenario-based simulations and projections are most vital to deliver valuable information for adequate disaster preparedness measures, i.e. evacuation planning, shelter building or contingency planning, for local communities and to foster long-term integrated coastal zone management strategies.

Thus, in order to perform accurate modeling of tsunami inundation and run-up, a very detailed model of near-shore bathymetry and coastal topography is mandatory to fulfill inherent planning demands on local administrative scales. Up-to-date tsunami scenarios for tsunami exposed coastlines worldwide rely on relative coarse data basis. Most often digitized nautical charts in combination with publicly available deep water bathymetry and near shore topography data are taken into account for first order risk assessment studies; also in the city of Padang (Borrero et al. 2006). On the other hand side for the benefit of adequate disaster preparation planning purposes, it is highly demanded to reflect more accurately the very near-shore bathymetries and assimilate data of existing coastal defense structures, river outlets and urban waterways as well as high resolution coastal topography data including main infrastructure and buildings in the areas of key interest as Taubenboeck et al. (2009) point out. Their novel approach defines a kind of second order risk assessment study.

Thus, the core of the present paper investigates the near-field tsunami propagation in shallow water environments and bore-like wave propagation on land to consequently derive useful highlyresolved hazard maps in the city of Padang, Western Sumatra, Republic of Indonesia.

\section{Local disaster risk reduction needs and knowledge gaps}

Apart from all technology and scientific knowledge based disaster preparation efforts stemming from the global scientific community, it is imperative that the national and local authorities in Indonesia ensure to realize that adequate disaster mitigation measures and preparedness schemes have to be taken into account in due time. Yet, without the society's understanding of the type and level of risk being exposed to, it is very difficult to advance and implement strategies for disaster risk 
reduction. It is quite often argued that the information and experience contained within the knowledgepractice-belief complex of communities and individuals is a most valuable, but often neglected area of information and understanding about past catastrophic events (King and Goff 2010). This apparent mismatch is also made obvious by Shah (2006) as he addresses the importance of and issues related to the so-called Last-Mile. In this regard Schiermeier (2009) points out that five years after the Indian Ocean tsunami disaster, the most sophisticated early warning sensor network and technology is in place, but local administrative and thorough preparedness efforts on the Indonesian coastlines are still less advanced, i.e. to some extent even underdeveloped. This is only partly due to a lack of national coordination frameworks in terms of mainstreaming decentralized local preparedness initiatives, but largely to missing sustainable coastal zone management schemes for shaping long-term spatial planning development and enabling administrative guidelines. So, the question remains whether we are reaching the people who represent and live on the Last-Mile of the pathway to effective mitigation. What is needed according to Shaw (2006) is to create true integration of local stakeholders with their own traditional knowledge and experiences to effectively mitigate disaster risks.

True impacts will only be achieved when hazard issues are fully recognized and community-based actions are taken to improve the situation. This implies understanding the socio-economic constraints in order to balance and interweave scientific and engineering insights and knowledge with nonscientific and non-technical matters, i.e. sources of indigenous knowledge, as the major role in implementing effective disaster risk reduction strategies.

\section{ACQUISITION AND PROCESSING METHODS OF GEODATA BASIS}

In general, research studies related to any kind of hazard mitigation strategy in terms to conduct risk and vulnerability assessments and developing risk reduction measures associated with geophysical or meteorological extreme events are crucially dependent on their underlying inherent spatial and temporal geodata basis of the region or area of interest. In order to enable adequate modeling approaches and, thus, to progress hazard and risk analysis and to deliver robust tools for decision support systems, it is a prerequisite to collect and assimilate high resolution and updated geodata. These include topography and bathymetry data or thematic maps of the region of interest where sets of geodata are categorically of low accuracy and resolution or even not available. Therefore, various remotely sensed and hydrographical data sets were acquired for Padang as well as field surveys were conducted, i.e. containing household questionnaires, to meet the terms of an overall accurate data basis.

\section{Remote sensing and bathymetrical surveys}

To perform accurate modeling of tsunami inundation and run-up, a detailed model of near shore bathymetry and coastal topography is an essential precondition. The spatial geodata basis found in the beginning of the project in 2007 lacked in terms of accuracy and resolution in order to conduct robust and trustworthy simulations of detailed tsunami propagation and impacts of surge-flow in the city. Nevertheless, this preliminary set of geodata allowed first, yet very coarse geographical representation of the city of Padang to assist detecting infrastructural bottlenecks and hot spots of vulnerability in sequence of tentative evacuation procedures.

In a following phase of this research study high resolution satellite imagery from the Ikonos satellite sensor with geometric capabilities of approximately $1 \mathrm{~m}$ in panchromatic and $4 \mathrm{~m}$ in multispectral bands have been acquired to extract highly detailed information on the individual physical objects of complex urban areas, i.e. buildings, streets and open spaces. The generation of a homogeneous map required post-processing of all collected image data. Satellite data were pansharpened and corrections due to atmospheric artifacts were processed. Preliminary geometrical representation and elevation heights of the area was accordingly derived from 1 arcs (approx. $30 \mathrm{~m}$ ) SRTM - Shuttle Radar Topography Mission data which have been obtained on a near-global scale to generate the most complete high-resolution digital topographic database of Earth. We initiated additional GPS measurements at distinctive locations in Padang (a total of 800 points) to validate and to adjust ground level elevations for follow-up processing. Artificial height differences in the topography were smoothed by applying low-pass filtering techniques. Constructional drawings of existing waterways and drainage channels as well as to some extent available single-beam echo soundings handed over by Padang municipal authorities were digitized in combination with digitized appropriate nautical charts and manually merged into the geographical representation of the area to finally set-up a first order DEM - Digital Elevation Model of the city of Padang. In order to significantly enhance this existing geodata basis leading to highly-resolved topographical information, 
the second phase of project ensued an airborne survey was conducted in Padang gathering appropriate data with even a higher resolution utilizing the MFC - Multi Functional Camera (Börner et al. 2008). The German Aerospace Center (DLR) developed a new generation of line cameras, which can be applied for space borne, air borne and terrestrial data acquisition. Its core is a CCD line module consisting of the imaging detector and the front end electronics. The application of an inertial measurement unit allows data acquisition with moving platforms. The unique MFC system is one of the most advanced digital aerial line scanner systems worldwide today. Characteristics of the camera include synchronous image data acquisition, with up to $16 \mathrm{~cm}$ spatial resolution, and detailed and highly automated processing of DSM - Digital Surface Models. Within the scope of this project the resulting processed geodata for the city of Padang were true orthophotos with a pixel-spacing of roughly $0.25 \mathrm{~m}$. Data were mapped and delivered in units of UTM/WGS 84 . The aerial survey collected about 2 TB of data and was accompanied by an infrastructure facade photographic campaign. Sample sections and buildings were photographed and locations measured by GPS to later establish an on-line available 3-D city model for identification of main infrastructure and visualization of evacuation routes and shelter buildings as key element of the decision support system (DSS) for disaster management.

In addition an autonomous survey to map the shallow water sea bottom and distinct bathymetrical features offshore and in the near-shore area of Padang has been conducted. This hydrographical survey has been carried out during Sept. to Nov. 2007 (see Taubenboeck et al 2009 for details). Roughly $42 \mathrm{~km}^{2}$ have been mapped by means of multi-beam echo sounding in combination with motion sensor correction and DGPS assistance. The acquired geodata have been finalized in post-processing to a uniformly spaced grid product of a $3 \times 3 \mathrm{~m}$ raster. Moreover, constructional drawings and data of the newly erected seawall and groin field along-shore the urban coastline (see fig. 1c) have been integrated into the geographical representation of the area to set-up a second order DTM - Digital Terrain Model

\section{Elevation models of the city of Padang}

Based on these independently obtained geodata sets two different geographical representations have been assembled for numerical tsunami propagation and inundation purposes representing the plain ground with adequate roughness attributions in characteristic spatial distribution (DEM) and the ground level elevation of the terrain including macro-structural elements (DTM) assimilating details of houses and urban infrastructure. In this context Figure 2 presents extracts of the model domains. Both geographical representations obviously reveal important infrastructural features and edges of landmarks. In terms of the physics of a tsunami and, likewise, its mathematical modeling these geometrical attributes and elements significantly characterize the near-shore tsunami propagation and onshore inundation as well as the leading flow paths along the main streets and in between buildings which cannot be resolved principally by the coarse DEM.

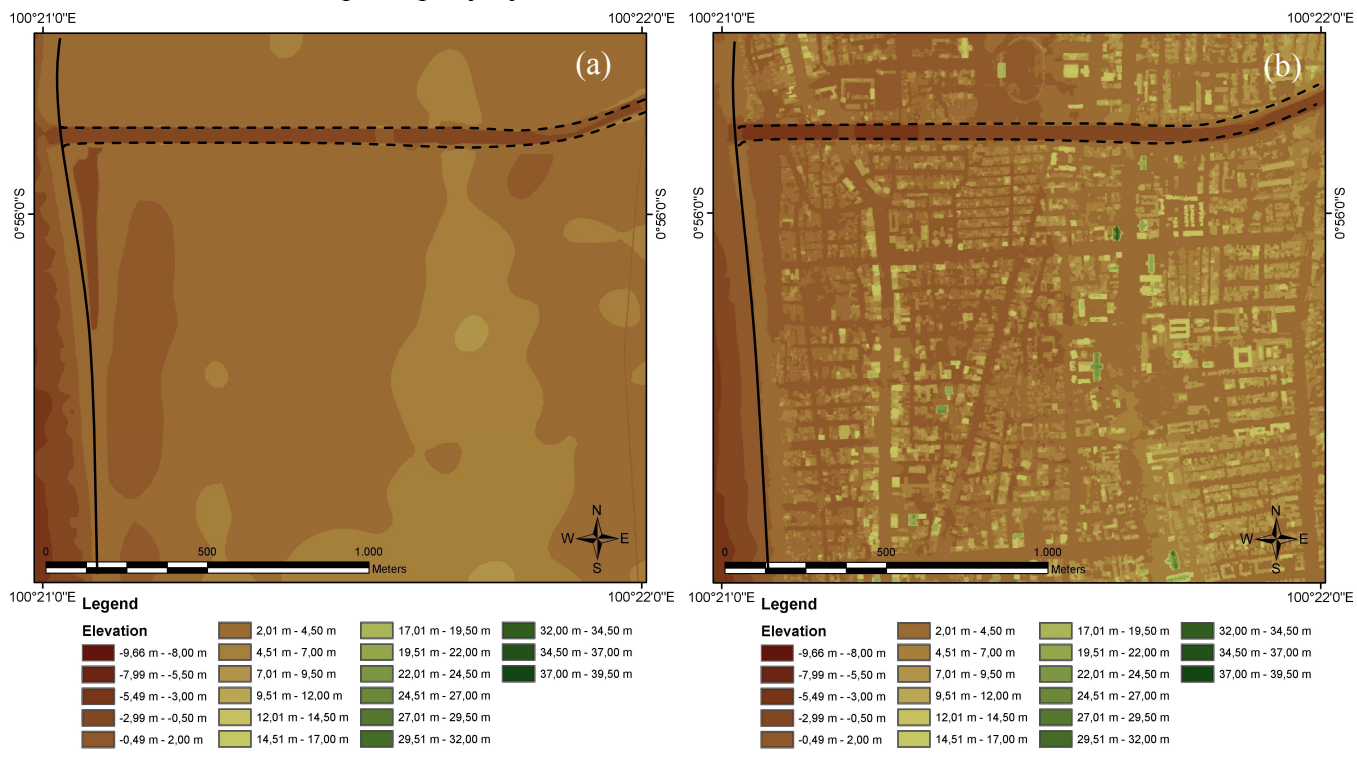

Figure 2. Geographical representation of the city of Padang in coarse DEM (a), and highly-resolved DTM (b). Elevations above MSL are given in [m]. The solid black line indicates the derived coastline and dashed black line illustrates the main course of the flood relief channel (FRC) of the city of Padang. 
The here shown extract of the model domain of Padang in Figure 2 properly reveals the main coastline, the mouth of the flood control channel and the overall topography of the terrain in either model. In contrast, considering the highly-resolved DTM, we found all major structural features of the city of Padang to be resolved extraordinary well. Footprints of the buildings and other infrastructure are in general captured effectively for these purposes as a resolution of roughly $0.25 \mathrm{~m}$ is achieved

In order to carefully assess relative accuracy and resolution of both underlying geographical representations Figure 3 juxtaposes the two independently obtained seafloor and terrain elevation heights by example of one selected cross section A-A which is depicted in the top panel of Figure 3. This examination is intended to differentiate between bathymetry and topography data acquired in the field missions and surveys conducted. Seafloor and ground level elevations of either geographical representation are plotted along the selected cross section A-A. The solid blue line depicts the elevation differences between both geometries. Yet, remarkable differences do exist between the two geometries in the shallow water region and likewise onshore in the city. In some locations bathymetries deviate by almost 50 percent in reference to the local water depth surveyed during the multi-beam echo sounding mission. This observation holds true for other cross sections in the near shore area of Padang, which are not shown here. The effect of bathymetry deviations in terms of tsunami propagation and, concurrently, intrinsic physical near-shore transitional processes is substantial and strongly distresses tsunami inundations and run-up heights in consequence. Elevation differences in topography onshore are likewise noteworthy since in the considered cross section A-A significant lower elevations within the highly-resolved DTM are exposed, especially in the important $1000 \mathrm{~m}$ wide coastal stretch from the shoreline. On the other hand side topography of the coastal hinterland is generally of higher elevation in the DTM than in the coarse DEM relying on the SRTM data, which are known for considerable inaccuracies in vertical magnitudes (Farr et al. 2007).

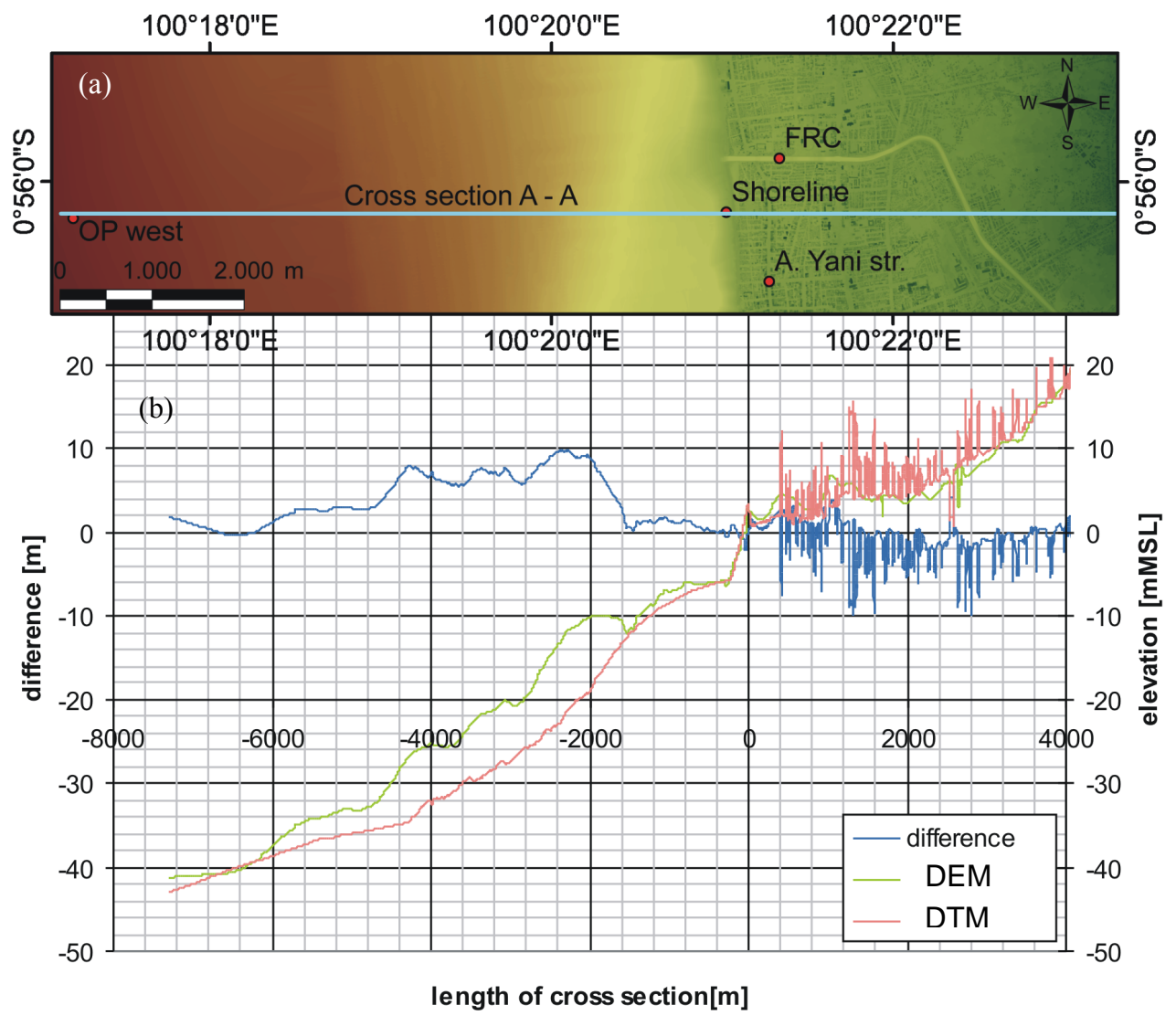

Figure 3. Assessment of relative accuracy of digital elevation (DEM) and digital terrain (DTM) model. Location and length of cross section A-A (a), and seafloor and ground level elevations of either geographical representation with green solid line representing DEM, red solid line representing DTM and blue solid line difference between DEM and DTM along the selected cross section A-A (b). 


\section{Tectonic observations and plausible seismic sources}

To understand the seismic and tsunami hazards of the Sumatran megathrust major, long-term investigations studying the behavior of the Sumatran section of the Sunda plate boundary are conducted by means of the Sumatran GPS Array (SuGAr) being designed, constructed and operated by members of the Tectonics Observatory at Caltech and the Indonesian Institute of Sciences (LIPI), in combination with field measurements of coral uplift, synthetic aperture radar (SAR), interferometry (InSAR) and seismological records (Chlieh et al. 2006, Subarya et al. 2006, Konca et al. 2008 and Sieh et al. 2008). All studies focus on both the intrinsic slip rates and locking depths of the Sumatran fault as well as on the behavior of the megathrust updip of the great 2005 and 2007 and the more recent ruptures. By best available techniques the kinematics of the $100-\mathrm{km}$ section of the megathrust are examined in order to describe how the Mentawai patch performs now and prior to its anticipated next cyclic great rupture that will according to Sieh et al. (2008) probably be completed within the next several decades.

By means of the GPS array stations arranged along a long stretch of Sumatra satellite-based seismic data on earthquake activity and valuable data in the region are collected. Horizontal GPS motions are measured trenchwards to establish a fault and collective slip model including cumulative displacements triggered by past earthquake which are yet contaminated by post-seismic relaxation. Vertical displacements are measured at the GPS stations and from the emergence or submergence of coral microatolls, respectively, which build ideal natural instruments on the reefs that fringe the Mentawai Islands. Coral microatolls are known to be sensitive natural recorders of lowest tide levels as their heads grow radially upward and outward until they reach an elevation that exposes their highest corallites to the atmosphere during lowest tides. This subaerial exposure kills the uppermost corallites in the colony, thus restricting future upward growth. In-situ records show sign of continuous uplift of the islands and subsidence of the mainland Sumatran coast; maximum uplift reaches $1.3 \mathrm{~m}$ on Mega Island about $70 \mathrm{~km}$ northwest of the epicenter of the 2007 earthquake. These data are complemented with InSAR line-of-sight displacements. If coral microatolls are then uplifted or subsided due to sudden tectonic changes leading to long-term vertical dislocations, its morphology preserves information about relative water level prior to the land level change (Konca et al. 2008 and Sieh et al. 2008).

These unique sources of information are further taken into consideration to determine static and kinematic source models from modeling of the surface displacements in addition with teleseismic waveforms of previous earthquakes recorded. According to Konca et al. (2008) the September 2007 sequence ruptured a certain number of distinct asperities on the megathrust situated within a patch that had remained strongly locked in the dormant period and within the rupture area of the 1833 earthquake. However, the patterns and amounts of slip in 1833 and 2007 are significantly different. The remaining moment deficit accumulated since 1833 is still less than the moment released during the 1797 and 1833 events. In fact Konca et al. (2008) affirm that the 2007 sequence did release only about $25 \%$ of the deficit of moment accumulated since 1833 . In reference to these analyses, McCloskey et al. (2009) recently evaluate the 30 September 2009 earthquake and conclude from seismic records and subsequent calculations that even this particular and most recent quake in the region did not rupture the Sunda megathrust, so that it insignificantly relaxed the accumulated stress on the Mentawai segment and argue that the megathrust strain-energy budget remains substantially unchanged. In consequence, the total regional slip deficit below Siberut and the Pagai Islands since the large ruptures from 1797 and 1833, and 30 September 2007, is approximately $8 \mathrm{~m}$, equivalent to a moment deficit corresponding to an $\mathrm{Mw}=8.8$ earthquake (Sieh et al. 2008). The conceivable next great rupture might be expected to occur north of $2^{\circ} \mathrm{S}$ and its likelihood to be devastating in nature is quite large.

By means of collecting and processing data from various resources and origins a thoroughly derived source model is established which provides a plausible picture of both estimated magnitude and extent of the underlying rupture dimension and co-seismic slip in the Mentawai region. Yet, this methodological approach is determined upon a set of variables and parameter as well as assumptions and source model simplifications. Each of these factors embeds inaccuracies and uncertainties which can be neither quantified fully nor verified against any measured observation or validated welladvanced theory. As a result the authors of this article recommend allocating a kind of deterministic safety factor of the order of 0.5 to artificially magnify, and, therefore significantly revise the underlying source model distribution due to its inherent complexity and unpredictability. Although this approach seems unfounded in scientific terms of which the authors are fully aware of, the here proposed procedure warrants at least some sort of safety margin for all subsequent steps of tsunami 
modeling and disaster mitigation procedures and strategies which in total are built upon further and inherent unquantifiable uncertainties and typical inaccuracies.

In order to obtain the initial sea-floor vertical displacement which is then being used as the initial sea surface height in the model, the analytical approach of the displacement fields of inclined faults by Mansinha and Smylie (1971) is applied. This phase is treated simply by translating an inferred oceanbottom displacement instantaneously into a similar displacement of the ocean surface and using that as input for a propagation model. Whereas Gisler (2008) values this approach as inappropriate and to some extent even misleading, the applied shallow-water equations and other vertically averaged approximations work reasonably well for long-distance propagation, but the generation region and the near-field effects are poorly served by these approximations.

By means of this source model a regional initial sea surface height pattern is produced and shown in Figure 4. Minimum and maximum sea floor vertical displacements are approximately $-1.5 \mathrm{~m}$ and $+3.5 \mathrm{~m}$, respectively. This distinct map of initial sea surface heights derived from the proposed fault model is then taken as input of the offshore boundary to the triggered tsunami model explained in the next sections.

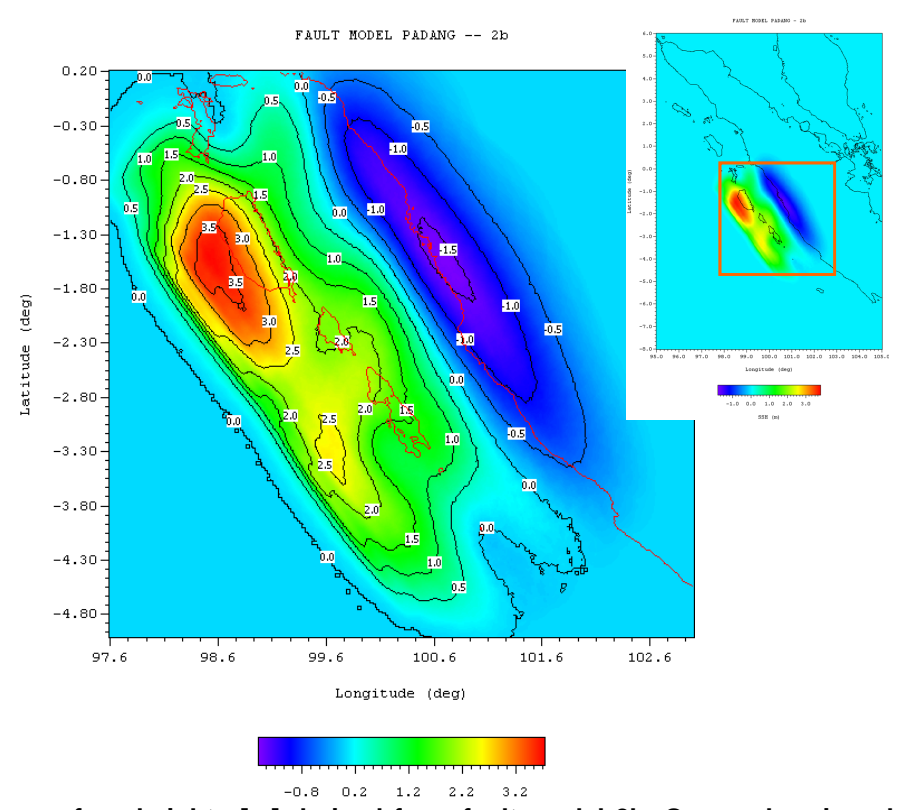

Figure 4. Map of initial sea surface heights [m] derived from fault model $2 \mathrm{~b}$. Orange box in subfigure (top right) depicts inset of initial sea surface heights in larger map. All models and data provided by $D$. Natawidjaja (personal communication).

\section{HYDRONUMERICAL TSUNAMI MODELLING}

Tsunamis propagate in the sea as gravity waves obeying classic laws of hydrodynamics. Since their wavelength is much larger than the water depth, they behave as long waves propagating in shallow water even though in water depths of a few thousand meters. High resolution of the bathymetric model, in particularly near the coast, is crucial for robust estimation of tsunami wave heights in shallow water since highly complex and nonlinear transitions take place and have critical effects on near-shore tsunami run-up and inundation on land.

Both numerical and physical modeling techniques are applied to study either one part or the complete process of generation, propagation and run-up in coastal waters. Nevertheless, in laboratory experiments scientists often face problems when replication of measured long wave time series from either moored ships ${ }^{4}$ or tidal gage records is necessary. Applying solitary waves instead of prototype time series in physical modeling is a common approach. Even though this approach covers a wide area of oceanographic and geophysical aspects, near-shore applications and the study of surge flow as well as wave run-up cannot be addressed appropriately due to scale effects. Wave lengths which are

${ }^{4}$ E.g the sea surface elevation recorded near-shore by the Mercator Yacht in Thailand in consequence of 26 December 2004 tsunami (Ward and Day 2008). 
attainable in the laboratory are by far too short compared to geophysical length scales given in prototype. Despite these constraints, Goseberg and Schlurmann (2010) present an alternative methodology in physical long wave generation in contrast to common wave making facilities. Nevertheless, correct reproduction and investigations on tsunamis in scaled physical environments remains challenging and is still to some extent an engineering work of art. However, due to these restrictions and performance limitations tsunami generation, propagation and run-up must be solved numerically, and there are a variety of schemes being developed and benchmarked in literature (Gisler 2008). A large number of groups worldwide have developed and established modeling tools for tsunamis and new developments in algorithms and computational facilities have enabled significant progress in this area as pointed out in a review conducted by Synolakis and Bernard (2006).

\section{Prerequisites and modeling scenarios}

Conceptually tsunami modeling considers three consecutive phases. First, the generation phase includes seismically triggered motion on the sea floor, causing a distinct displacement of the water body and exchange of energy and momentum into the water. The second step regards the propagation phase and results in a traveling wave train in two surface dimensions over a seafloor of varying depth. The foremost complex third part considers chief transitional processes, namely shoaling, inundation and run-up along with other near-shore processes. These occur as the tsunami encounters the coastline. Although these phases are interwoven with each other, and can be demanding to separate or treated individually, aspects of the physics are differently stressed in one phase relative to another.

The main calculation approach considered in literature regards the so-called shallow-water, or long-wavelength, approximation and resembles the simplest of several depth-averaged approaches that are used to study long-wave propagation. In shallow water wave theory, the vertical accelerations and velocities are neglected, and the pressure is assumed to be hydrostatic and therefore a linear function of the depth. In this research study, two basic numerical tools are applied in a hybrid methodological approach. For the numerical modeling of the near-shore tsunami inundation process two numerical codes are coupled. The tsunami generation and propagation of the long wave train in the far-field have been computed by means of TUNAMI N2 (Goto et al. 1997). This well-recognized and broadly applied numerical code solves the nonlinear shallow water wave equations on a structured grid. The explicit leap-frog scheme is employed to solve the governing equations using a central difference scheme with a truncation error of second order. Although computational efficiency is relative high, six nested grids covering the main tsunami propagation region significantly reduce the number of computational cells. The resolution of the sub grids is primarily tied with the underlying correspondent geodata resolution. Table 1 lists some of the important parameters for the TUNAMI simulation.

\begin{tabular}{|c|c|c|c|c|c|c|c|c|}
\hline \multirow[t]{2}{*}{ Domain } & \multicolumn{2}{|c|}{ No. of cells } & \multicolumn{2}{|c|}{ Longitude $\left({ }^{\circ}\right)$} & \multicolumn{2}{|c|}{ Latitude $\left({ }^{\circ}\right)$} & \multirow{2}{*}{$\begin{array}{c}\text { Edge length } \\
(\mathrm{m})\end{array}$} & \multirow{2}{*}{$\begin{array}{c}\begin{array}{c}\text { Time } \\
\text { step }(\mathrm{s})\end{array} \\
\mathrm{dt}\end{array}$} \\
\hline & $\mathrm{X}$ & $\bar{Y}$ & minimum & maximum & minimum & maximum & & \\
\hline 01 & 914 & 1279 & 95.000000 & 105.000000 & 6.000000 & -8.000000 & 1216.14 & 1.0 \\
\hline 02 & 277 & 331 & 99.656263 & 100.665777 & -0.371658 & -1.575767 & 405.38 & 1.0 \\
\hline 03 & 572 & 653 & 99.878669 & 100.573600 & -0.610923 & -1.404737 & 135.26 & 0.5 \\
\hline 04 & 934 & 871 & 100.075846 & 100.454116 & -0.776288 & -1.129124 & 45.06 & 0.3 \\
\hline 05 & 1649 & 1507 & 100.197668 & 100.420491 & -0.861872 & -1.065505 & 15.04 & 0.2 \\
\hline 06 & 2784 & 2281 & 100.268177 & 100.393553 & -0.875714 & -0.978461 & 5.01 & 0.1 \\
\hline
\end{tabular}

The geodata applied for the far-field modeling of the wave generation and propagation of this simulation chain originates primarily from Gebco (IOC, 2003) database. In the shallow regions of the nested domain six existing data sets of the seafloor have been enhanced by a newly derived hydrographic data (Goseberg et al. 2009). Approximately $42 \mathrm{~km}^{2}$ off the coast of Padang have been mapped by means of multi-beam echo sounder with sensor-based ship motion correction and DGPS assistance. The acquired data were finally merged to establish a uniformly formatted grid with a spatial resolution of $3.00 \mathrm{~m}$. All remaining data gaps have been either interpolated or filled up with digitized nautical charts and data of coastal infrastructures as announced in of the preceding paragraphs.

In a second step, the hydrodynamic modeling tool ANUGA (Nielsen et al. 2005) is applied for the correlating numerical simulations on tsunami run-up and inundations in the near-field. ANUGA uses a finite-volume approach to solve the nonlinear shallow water wave equations in conservative form. A spatially varying triangular mesh is used for discretization of the considered area of interest. The conserved quantities are water depth and horizontal momentum in $\mathrm{x}$ - and y-direction (Nielsen et al. 
2005). A detailed description of the applied numerical scheme can be found in the work of Zoppou and Roberts (1999). The chosen coupling strategy between the far-field TUNAMI N2 based simulations only allows unidirectional propagation of the incident wave into the nested ANUGA domain.

Modeling the near-shore hydrodynamic processes in a subsequent step with the finite-volume approach implemented in ANUGA demands significantly more computational resources than finite differences based implementations. Therefore domain decomposition and parallel computation facilitates the simulation and a considerable speed-up could be denoted. The full ANUGA domain is decomposed into eight sub domains. Table 2 lists the constitutive modeling parameters of the ANUGA simulations and the associated sub domains. The extent of the bounding boxes is given relative to the lower left corner of the full domain. The absolute coordinates are $X=632968$ and $Y=9880202$. The time step of the simulations is in the range of $t=0.017-0.055 \mathrm{~s}$ according to the CFL criteria. Throughout the modeling attempts with ANUGA model runs have been computed with a total model time of $8000 \mathrm{~s}$. The associated areas of the triangular computational cells vary through the full domain depending on the underlying bathymetric and topographic resolution and its accuracy. In the city center of Padang the triangle size is of order of magnitude of the acquired topographic raster edge length in order to fully capture and integrate the built infrastructure.

\begin{tabular}{|c|c|c|c|c|c|c|c|}
\hline \multirow[t]{3}{*}{ Domain } & \multirow[t]{3}{*}{ No. of triangles } & \multicolumn{2}{|c|}{ Triangle area $\left(\mathrm{m}^{2}\right)$} & \multicolumn{4}{|c|}{ Bounding box extent (WGS84, UTM 47S) } \\
\hline & & \multirow[t]{2}{*}{$\min$} & \multirow[t]{2}{*}{$\max$} & \multicolumn{2}{|c|}{$\mathrm{X}$} & \multicolumn{2}{|c|}{$\mathrm{Y}$} \\
\hline & & & & $\min$ & $\max$ & $\min$ & $\max$ \\
\hline P0 & 408787 & 4.89 & 14978.59 & 15705.93 & 19906.35 & 22060.00 & 24550.88 \\
\hline P1 & 407952 & 3,84 & 14983.99 & 14604.75 & 22566.57 & 20931.07 & 24553.31 \\
\hline $\mathrm{P} 2$ & 411367 & 5.57 & 8072.55 & 15522.05 & 18940.86 & 18795.74 & 22456.68 \\
\hline P3 & 410137 & 2.85 & 14930.67 & 17138.20 & 22684.49 & 19405.15 & 23057.51 \\
\hline $\mathrm{P} 4$ & 408441 & 3.67 & 14972.72 & 15828.41 & 25682.89 & 10484.91 & 16005.44 \\
\hline P5 & 408755 & 3.21 & 14244.46 & 15045.23 & 19870.23 & 12678.72 & 16681.49 \\
\hline P6 & 410542 & 3.09 & 14989.54 & 17577.58 & 25681.47 & 15055.15 & 21409.15 \\
\hline $\mathrm{P} 7$ & 407716 & 3.00 & 14999.78 & 0.00 & 25711.00 & 0.00 & 24553.63 \\
\hline
\end{tabular}

Figure 5 depicts the general coupling strategy between TUNAMI and ANUGA and outlines the eight computational sub domains in ANUGA given in table 2. The right hand side of figure 5 shows the ANUGA domain that takes its input from the TUNAMI results. At the interface between both modeling domains ANUGA is supplied by the time histories of sea surface elevation and horizontal momentum denoted by the red circles. Since the ANUGA mesh is still distributed in a much finer resolution at its domain boundaries, the input information is linearly interpolated in space and time.

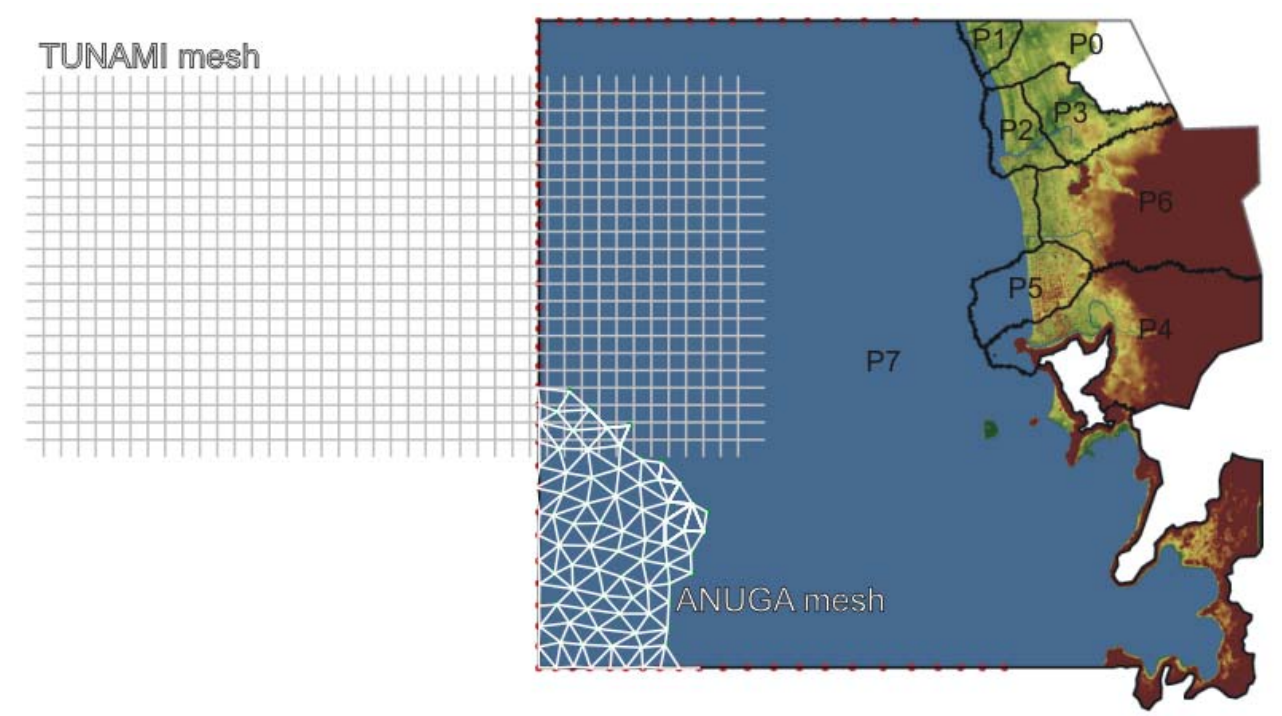

Figure 5. Schematic illustration of applied coupled numerical models TUNAMI and ANUGA. Interface is depicted by red circles distributed along the ANUGA domain boundaries; light grey grid schematically demonstrated the rectangular TUNAMI grid of sixth nested domain, while the white triangular mesh depicts the numerical grid of the ANUGA model. 
Adapted from the tectonic settings and the plausible rupture scenarios vertical seafloor displacements are generated based on the methodology of Masinha and Smylie (1971) from the rigidity and the estimated interlocking at the plate boundary. Vertical deformations at the sea bottom have been used to establish the initial sea surface elevation for the hydronumerical computations. Co-seismic subsidence at Padang has been accounted for, i.e. for scenarios SID-01 to SID-04 it comprises to $\Delta \mathrm{z}=-0.84 \mathrm{~m}$ uniformly distributed on the confined modeling domain, and for scenarios SID-05 to SID-08 the region subsides by $\Delta \mathrm{z}=-1.38 \mathrm{~m}$.

Apart from this straightforward methodological approach it was imperative to consider further detrimental parameter or options that could influence the overall inundation extent and the flow dynamics in order to determine a kind of worst-case scenario. Meeting these requirements a total number of eight specific scenarios are proposed for the city of Padang. These scenarios are given in table 3 . It is noted that buildings and infrastructures are rigid structural elements in DTM.

\begin{tabular}{|c|c|c|c|c|c|c|}
\hline Scenario identifier (SID) & Source $1 b$ & Source $2 b$ & MSL & MMHWL & DEM & DTM \\
\hline SID-01 & $\mathrm{X}$ & & $\mathrm{x}$ & & $\mathrm{x}$ & \\
\hline SID-02 & $\mathrm{x}$ & & & $\mathrm{x}$ & $\mathrm{x}$ & \\
\hline SID-03 & $\mathrm{x}$ & & $\mathrm{x}$ & & & $\mathrm{x}$ \\
\hline SID-04 & $\mathrm{x}$ & & & $\mathrm{x}$ & & $\mathrm{x}$ \\
\hline SID-05 & & $\mathrm{x}$ & $\mathrm{x}$ & & $x$ & \\
\hline SID-06 & & $\mathrm{x}$ & & $\mathrm{x}$ & $\mathrm{x}$ & \\
\hline SID-07 & & $\mathrm{x}$ & $\mathrm{x}$ & & & $\mathrm{x}$ \\
\hline SID-08 & & $\mathrm{x}$ & & $\mathrm{x}$ & & $\mathrm{x}$ \\
\hline
\end{tabular}

The scenarios are numbered consecutively based on either tsunami source, i.e. $1 \mathrm{~b}$ or $2 \mathrm{~b}$. The latter is the $50 \%$ magnified source model of source $1 \mathrm{~b}$ in order to compensate for uncertainties and inaccuracies as described in an earlier paragraph. In regard to possible coincidence of the tsunami with tidal water levels, two initial water levels have been determined and applied. Either the usual mean sea level (MSL) is taken or the mean of the monthly highest water level (MMHWL) of $0.80 \mathrm{~m}$ above mean sea level has been incorporated into the scenario development. Finally, variations in surface elevation due to infrastructure have been accounted for by means of applying either DEM or DTM.

\section{Inundation and hazard mapping}

In this context, considering SID-06 and SID-08 figure 6 denotes the significance of tsunami inundation extent applying either geographical representation, i.e. DEM or DTM. Obviously, the nonexistence of vertically oriented structures such as buildings or other infrastructure exposes relative smaller influence on resistances and block obstructions which are opposing the incoming tsunami. This evident and physically-sound divergence can be expressed in terms of maximum inundated area of $\mathrm{A}_{\max }=39.63 \mathrm{~km}^{2}$ for scenario SID-06 and $\mathrm{A}_{\max }=25.59 \mathrm{~km}^{2}$ for scenario SID-08. Concurrently, the tsunami surge flow reaches far more inland in reference to the geographical representation. In reference to the flood relief channel (FRC), the tsunami reaches $x_{\max }=1570 \mathrm{~m}$ in SID-08 and $\mathrm{x}_{\max }=2410 \mathrm{~m}$ in SID-06 into the urban hinterland. As indicated in table 3 and after lengthy, but fruitful discussion in the scientific community scenario SID-08 has been identified to represent the best, yet most physical sound mathematical interpretation of the existing urban settlement area in Padang, although SID-08 yields more confident inundation extent and penetrates less far inland than SID-06. It is simply regarded as the most adequate numerical and physical sound representation of onshore wave propagation. Thus, due to the unique set geodata in the given excellent quality and accuracy represented in the DTM, the application of the common digital elevation model (DEM) has been discarded in the case of Padang since the flow retarding effects caused by vertical roughness elements opposing the incoming tsunami-induced surge flow could obviously not be ignored.

This finding is in straight correspondence with a study carried out by Imamura (2009) who distinguishes between two applied methods in case of the existence of vertical structures on the coastline. Equivalent magnitudes of Manning coefficients could be employed to mimic the large-scale effects due to the vertical roughness elements. But, only few approaches are given in literature how to estimate these roughness coefficients correctly so that the integration of built infrastructure into the model domain is recommended once geodata is acquired and made available to modeling attempts. 

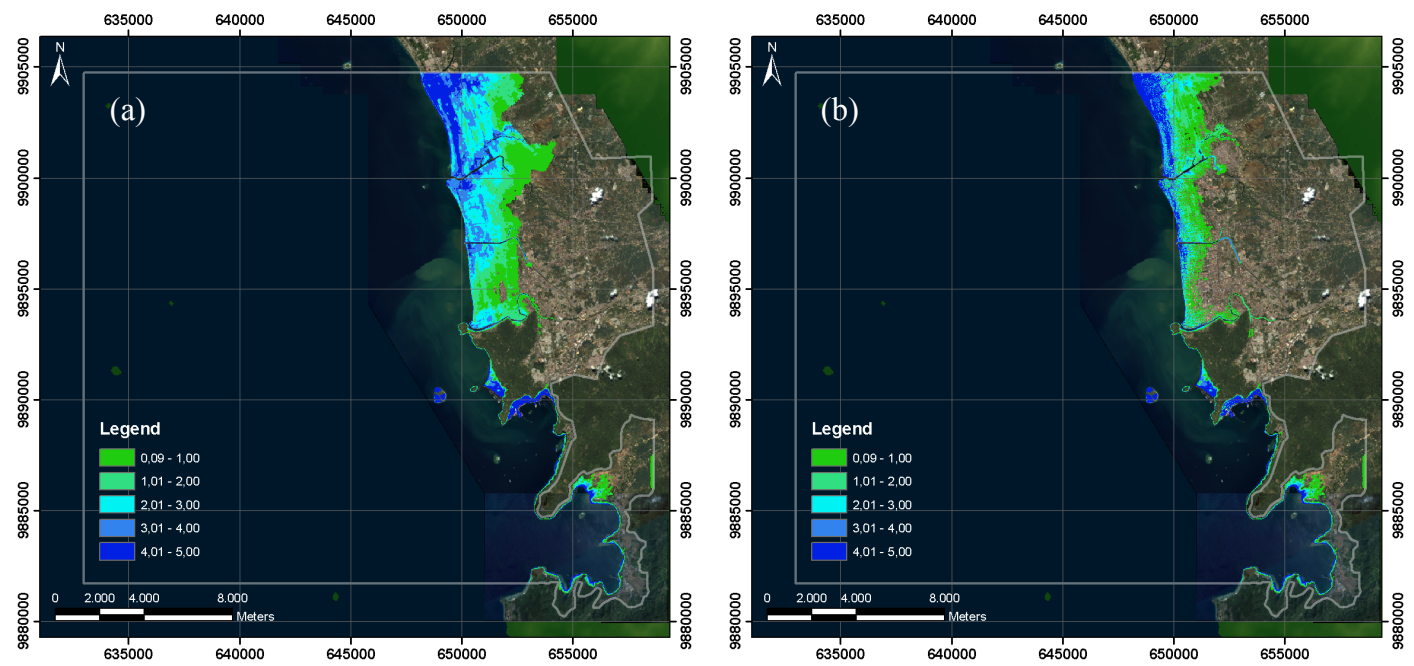

Figure 6. Maximum run-up and inundation for Scenarios SID-06 (a) and SID-08 (b), run-up heights are given in [m]; grey contour lines depict model domains.

Due to the unique set of highly-resolved geodata made available in the current study the representation of the digital terrain model (DTM) is recommended for further applications. Especially the convergence of the onshore tsunami-induced flow field in between the macro roughness elements, known from conventional Hydraulic Engineering as a Venturi effect, as well as the flow separation after passing the blocked obstructions is well captured by this geographical representation and consequent numerical approach.

Based on these leading arguments and in line with discussions and decisions made within the scientific community and local authorities attending the 2nd Padang Consensus workshop held in April 2010 along with reviewer remarks, two sets of cartographic products representing the Official Tsunami Hazard Map Padang have been compiled and recommended to progress disaster mitigation planning. Examples of products in 1:5000 scales are given in figure 7.
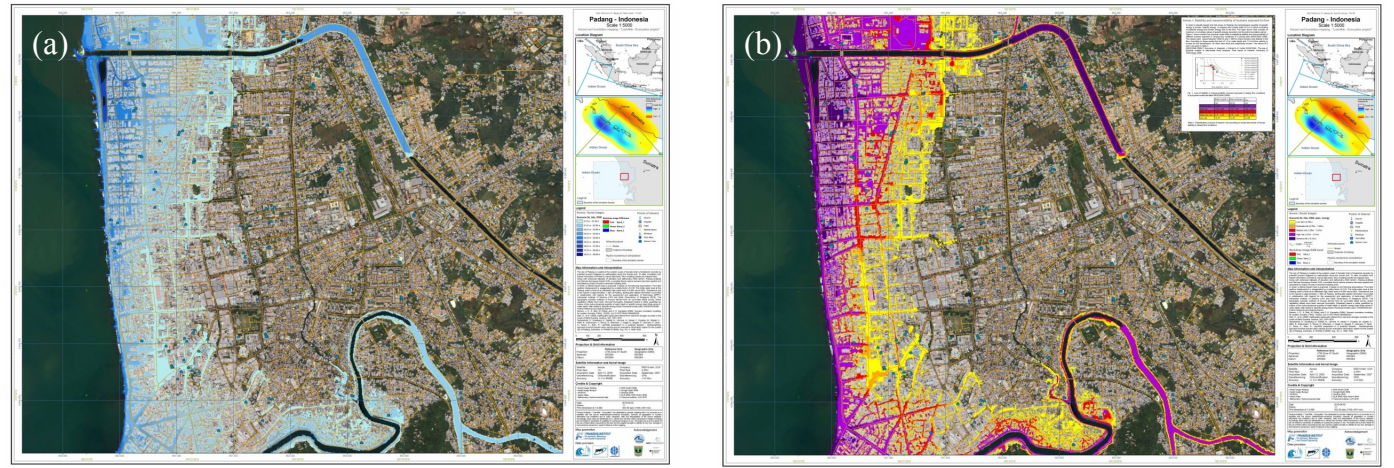

Figure 7. Tsunami inundation map originating from scenario SID-08 (a), Specific energy tsunami inundation map originating from scenario SID-08 (b) in the city of Padang in 1:5000 scale (see also supplementary material), English and Indonesian translation available and suitable for A0 map reproduction.

While evacuation zoning frequently demands information on the tentative inundated area, detailed constructional planning on infrastructure analysis requires information about momentum or energy being exposed to gain insight about impacts and possible damages by the tsunami. Besides the commonly known and often applied tsunami inundation maps, in the present case of Padang the hazard is characterized by means of the specific energy head estimated according to $E_{\text {specific }}=d+v^{2} /(2 g)$, where $d$ denotes the water depth $[\mathrm{m}]$ and $v$ the tsunami-induced current onshore $[\mathrm{m} / \mathrm{s}]$. The computation of the specific energy in reference to fig. $7 \mathrm{a}$ is depicted in figure $7 \mathrm{~b}$. The specific energy head integrates the potential energy in addition to kinetic energy induced by the current. The layer shown here regards the maximum of specific energy recorded over the entire simulation period in the city of Padang. 


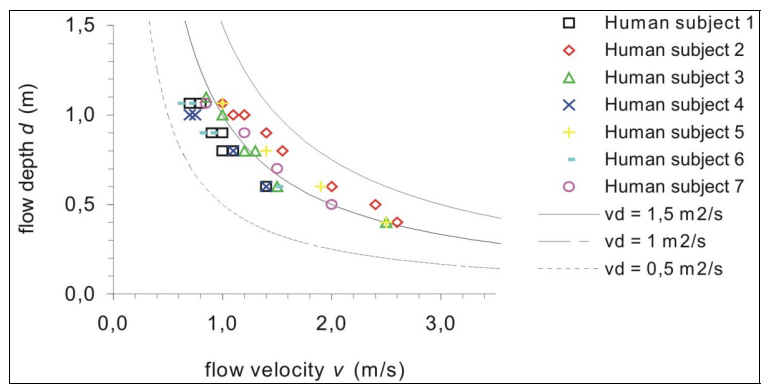

Figure 8. Maneuverability and stability of human beings exposed to steady state flow conditions for different water depth and flow velocities (Karvonen et al. 2000) for evacuation planning purposes.

In addition to these fundamental calculations on specific energy heads, figure 8 presents results from physical model tests investigating the stability and maneuverability of human beings exposed to varying flow conditions carried out in a towing tank (Karvonen et al. 2000). The results yield flow velocities in between $0.64 \mathrm{~m}^{2} / \mathrm{s}$ and $1.26 \mathrm{~m}^{2} / \mathrm{s}$ where human beings lose their stability in the attacking current and in consequence fall over. According to these results and to gather crucial information for succeeding evacuation simulations, the water level limit of $1.0 \mathrm{~m}$ and flow velocity of $1.0 \mathrm{~m} / \mathrm{s}$ is recommended for the subsequent mapping and evacuation classifications.

\section{Performance assessment between TUNAMI and ANUGA}

Tsunami inundation maps and time histories of run-up sequences stemming from two different numerical models are generated in order to assess the numerical performance of tsunami propagation onshore. While ANUGA comprises triangles of area $\sim 3.0-4.0 \mathrm{~m}^{2}$, TUNAMI uses marginally larger mesh cells of $25 \mathrm{~m}^{2}$. Agreement is found in time histories comparison at two different virtual gauge positions in the modeling domain. Figure 9 depicts results for SID-08. Tsunami amplitudes and phases are in good agreement. The virtual gauge at the western boundary of the model domains (figure 9a) concurrently constituting the interface between the two numerical codes demonstrates straight agreement in time domain. This also proves that the proposed coupling methodology operates convincingly in order to transfer the main driving forces through model domains without any loss. At the mouth of river Arau (figure 9b) the significantly transformed incoming tsunami splits up into a wave train of three successive main waves. The leading wave front exceeds a wave height of $\mathrm{h}_{\max , 1}=6.70 \mathrm{~m}$. While the second wave crest is only about $\mathrm{h}_{\max , 2}=2.00 \mathrm{~m}$ and might presumably, but falsely indicate less heightened tsunami alert, the third wave crest again reaches a wave height of $\mathrm{h}_{\max , 3}=5.00 \mathrm{~m}$.

It is most likely that the impact of the leading wave front while reaching the shore will cause severe damages in the vicinity of the coastline, so that numerous houses and infrastructure will be presumably destroyed within a distance of 500-1000 $\mathrm{m}$ from the shoreline and in 1000-1500 $\mathrm{m}$ on the river banks in one instant in time.
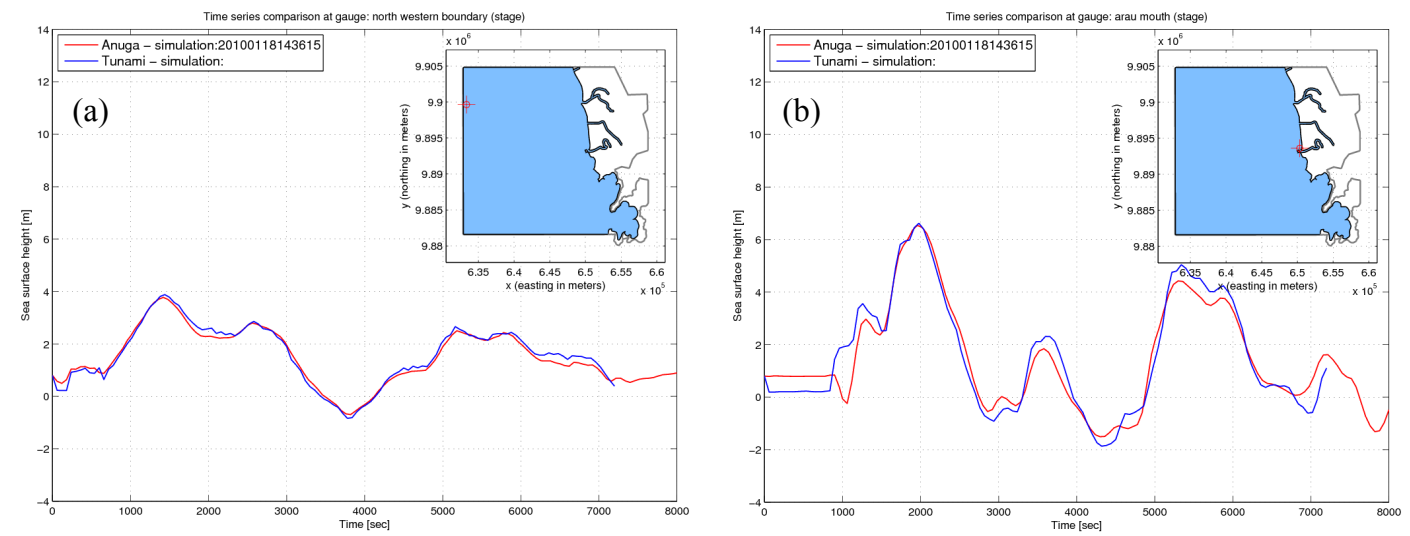

Figure 9. Comparison of water level time histories at two different position for the scenario SID- 08 between ANUGA and TUNAMI model results in meter, at the river mouth of Arau river (left) and at the western boundary (right), red graphs indicate ANUGA results, blue connote TUNAMI results. 


\section{DISSEMINATION AND KNOWLEDGE TRANSFER}

As pointed out earlier, any conceptual as well as operational design of a tsunami early warning system have to acknowledged and embed local structures, actors and capacities to create an integrated, so-called end-to-end system. Local authorities and affected people have to be made aware and adequately prepared of natural hazards in order to anticipate issued warning dossiers in a proper way and react adequately. Thus, it has been a primary objective to raise awareness and help developing appropriate preparedness strategies and mechanisms by achieving a numerical last-mile tsunami early warning and evacuation information system which delivers concrete evacuation recommendations for most credible tsunami inundation scenarios and methodologies for optimized evacuation circumstances with the local authorities and scientist in a joint research and communication approach.

From the beginning of all research and socialization activities in the city of Padang to adequately prepare for future tsunami hazards, it was envisioned to integrate local stakeholders and authorities, nongovernmental organizations as well as to a collaborate to a maximum degree with the scientists and researchers from Andalas University (UNAND) in addition to national experts into the tsunami study and evaluation process. Thus, a sizeable series of consultation talks and workshops; apart from the above stated Padang Consensus Process, with local experts have been conducted. Moreover, bathymetrical and topographical surveys and socio-economic campaigns as those describe by Taubenboeck et al. (2009) have been jointly carried out in order to maximize the capacity building impact and help enabling, yet, facilitating measuring, processing and interpreting geodata to advance knowledge in the city of Padang.

However, this objective has been only partly accomplished since it is essential to recognize that the local government of a district or city plays the most significant, yet, the crucial role when developing and initiating to execute research projects due to the fact the decentralization and democratization processes are still in progress. It was evident that districts (Kabupaten) and cities (Kota) permanently receive more and more competencies and responsibilities from the Indonesian government; especially in relation to disaster management and prevention policies. By constitution the Lord Mayor has the authority of making decisions in disastrous events, e.g. whether a city or coastal stretch is being evacuated or not due to any hazard or any other harmful occasion. So, the long-term and sustainable distribution of resources and civil protection of citizens in the city of Padang is steered and maintained by the local authorities themselves. Decisions and processes are being taken and initiated by these institutions, respectively, and of course, responsibilities are also taken by them.

In fact, the stringent decentralization process within a country like Indonesia is sort of beneficial for customized local disaster management schemes and likewise advantageous for an anticipated rapid response to tsunami warning dossiers in terms of evacuation. Therefore, the authors of this paper along with other colleagues and research as well as the local capacity building initiatives conducted and reported by Spahn et al. (2010), had to constantly elucidate, yet, interpret whether the local authorities and capacities are defined and how these (new) institutions are mandated to develop and operate an efficient combination of effective, interdisciplinary, integrated system in order to establish wideranging disaster management plans in the city of Padang. It is acknowledged that the establishment of local disaster management schemes, relevant policy-making and its implications in Padang are today still in progress. It has to be made clear that it is far out of scope of any of the involved research groups and beyond any scientific objective to keep track of state and anticipate trends of local policy-making and governance structures in the related field of disaster management.

Nevertheless, first steps have been successfully accomplished towards an effective local tsunami early warning system in Padang by jointly developing, discussing and finalizing an official set of tsunami hazard and risk maps and help commencing to generate and upgrade further preparedness measures and implications for adequate disaster management, although a long road is still ahead.

\section{DEMANDS AND OUTLOOK}

In order to maintain and update local disaster preparedness management schemes in the city of Padang it is most vital to take action in due time. As outlined beforehand, within the scope of present research activities microscopic temporal and spatial tsunami inundation dynamics have been taken into account to set-up an official set of tsunami hazard and risk maps for the city of Padang. This objective has been achieved by multinational scientific efforts by researchers from Indonesia, USA, Japan and Germany in collaboration with local scientists and municipal authorities from Padang mid April 2010 by generating an Official Tsunami Hazard Map Padang which has been approved by the Lord Mayor of Padang in May 2010. This official tsunami hazard map is highly demanded for further planning and 
preparedness processes in order to proceed with the development of a community friendly evacuation plan by involving relevant stakeholders.

This step is highly relevant considering additionally conducted assessments on the physicaltechnical susceptibility and the socio-economic vulnerability of the population with the objective to mitigate human and material losses due to possible tsunamis threats. By means of discrete multi-agent techniques risk-based, time- and site-dependent forecasts of the evacuation behavior of the population and the flow of traffic in large parts of the road system in the urban coastal strip have been simulated to achieve essential knowledge on how to evacuate the city most effectively and obtain vital insights in which locations to establish and construct vertical evacuation shelters.

The findings of this evacuation study are most remarkable, i.e. alerting for local authorities and research community. The outcome identifies that about 265.000 people are living in the highly exposed potential tsunami inundation area based on the official tsunami hazard map. Taking an assumed $500 \mathrm{~m}$ wide evacuation buffer zone as safe area neighboring the inundation area into consideration, only a fraction of the exposed citizens are expected to be capable to evacuate in due time, i.e. in less than approximately $30 \mathrm{~min}$. after the leading wave front of the tsunami following a major earthquake on the Sumatran fault reaches the shorelines. Figure 7 illustrates this depressing, but alleged realistic scenario and indicates rough evacuation times on the basis of computational benchmark solutions relying on the current infrastructures and the existing street network, but assuming both a rational and well trained population and an optimized solution for an evacuation taking pedestrians only into account.

Evidently, merely a number of approximate 170.000 people living far more inland are likely to reach safe evacuation areas and shelters in suitable time $<30 \mathrm{~min}$., but simulations also indicate that major parts of the city, especially the densely-populated coastal areas and waterways, are impractical to be evacuated within the first $30 \mathrm{~min}$. after a quake ruptured the area and may have triggered a tsunami, i.e. more than 95.000 people in the city of Padang will most probably need more than $30 \mathrm{~min}$. to evacuate to safe areas.

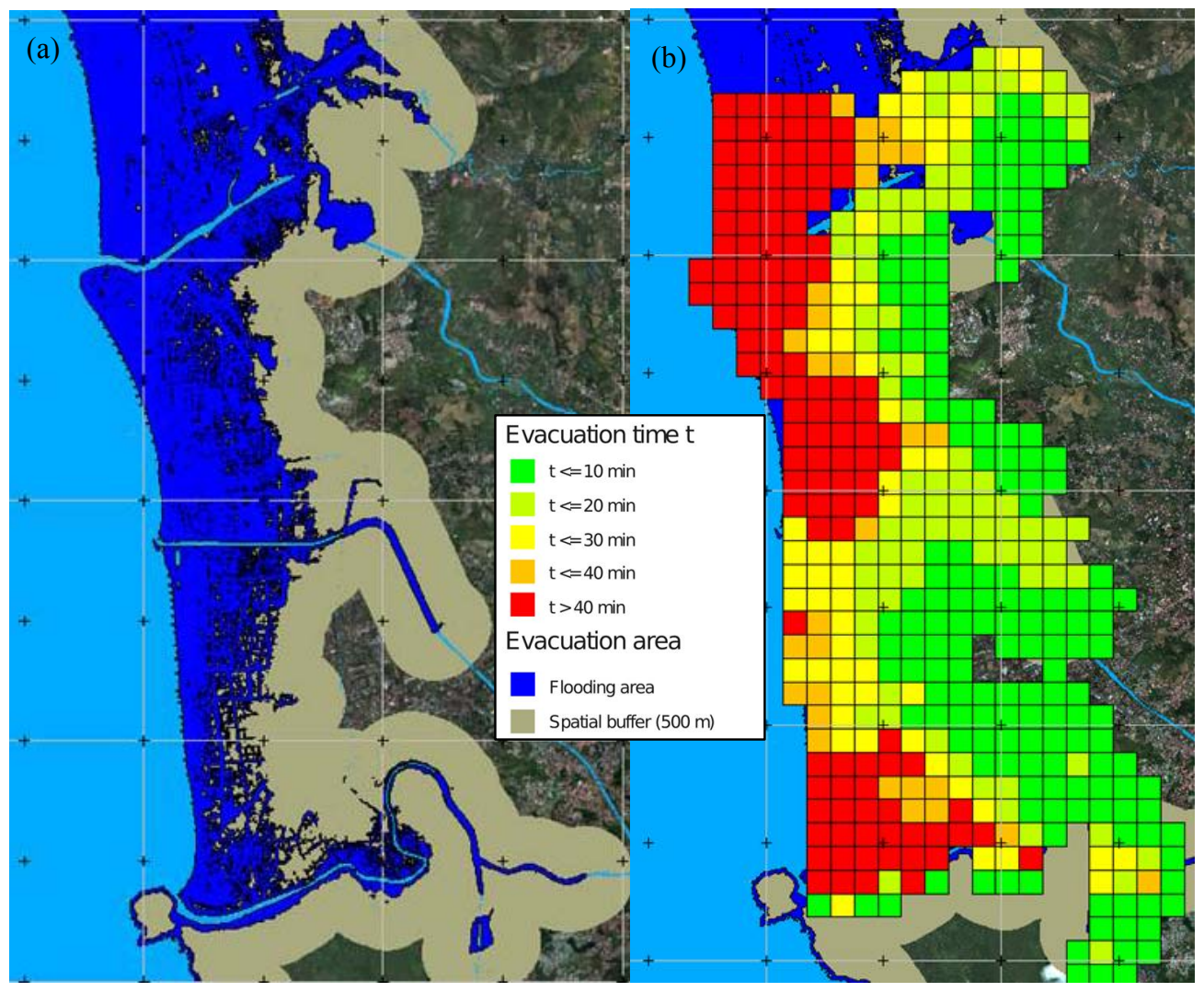

Figure 10. Tsunami inundation area from SID-08 and $500 \mathrm{~m}$ wide evacuation buffer zone indicated as lightbrown belt neighboring the tsunami inundation area (a), and minimal evacuation times [min.] to reach evacuation zone by foot (b) [taken from Schlurmann et al. 2010]. 
Depicting that framework and given the tragic loss of life and severe damages resulting from the September 2009 Padang earthquake, the need for urgent mitigating action in Padang remains extremely high. We hope that our study will help motivating and enabling improved disaster risk assessments and adequate response strategies leading to effective counter measures and preparedness mechanisms.

It has been recently announced that Swiss Reinsurance Company (Swiss Re) has decided to fund a new Geohazards International (GHI) project to design and prove a prototype vertical tsunami evacuation structure for the city of Padang.

What is more is that the goals and objectives of this joint study are most significant for mainstreaming scientific approaches and to transfer this methodological disaster risk reduction attempt towards other regions exposed to coastal hazards within Indonesia. Local Padang authorities could now distribute their knowledge and planning experience to other coastal regions.

\section{ACKNOWLEDGMENTS}

The authors would like to thank for financial support being enabled by the DFG/BMBF special Programme "Geotechnologies" - Early Warning Systems in Earth Management. Sponsorship Code: 03G0666A-H. We would also like to thank our partners from Andalas University as well as the provincial and city authorities in the city of Padang, West Sumatra, and RISTEK and all other relevant institutions for the support and outstanding assistance to help achieving an adequate and state-of-theart research data base in Indonesia.

\section{REFERENCES}

Bernard, E. N., Mofjeld, H. O., Titov, V., Synolakis, C. E. and F. I. Gonzalez. 2006. Tsunami: scientific frontiers, mitigation, forecasting and policy implications. Phil. Trans. R. Soc. A, Vol. 364, pp. 1989-2007

Birkmann, J., Dech, S., Goseberg, N., Lämmel, G., Moder, F., Nagel, K., Oczipka, M., Schlurmann, T., Setiadi, N., Siegert, F., Strunz, G. and H. Taubenböck, H., 2008a. Numerical Last-Mile Tsunami Early Warning and Evacuation Information System, Proc. International Conference on TsunamiWarning (ICTW), Bali, Indonesia, 12 pp., 12-14 November 2008

Birkmann, J., Setiadi, N. and N. Gebert,2008b. Socio-economic vulnerability assessment at the local level in context of tsunami early warning and Evacuation planning in the city of Padang, West Sumatra, Proc. International Conference on TsunamiWarning (ICTW), Nusa Dua, Bali, Indonesia, 12-14 November 2008

Börner, A., Hirschmüller, H., Scheibe, K., Suppa, M. and J. Wohlfeil. 2008. MFC - A Modular Line Camera for 3D World Modulling. Lecture Notes in Computer Science, Vol. 4931, pp. 319-326

Borrero, J. C., Sieh, K., Chlieh, M., and C. E. Synolakis. 2006. Tsunami inundation modeling for Western Sumatra, Proceedings of the National Academy of Sciences of the United States of America, Vol. 103 (52), pp. 19673-19677

Chlieh, M., Avouac, J. P., Sieh, K., Natawidjaja, D. H. and J. Galetzka. 2006. Heterogeneous coupling of the Sumatran megathrust constrained by geodetic and paleogeodetic measurements. Geophysical Research, 2008, 113

Farr, T.G., Rosen, P.A., Caro, E., Crippen, R., Duren, R., Hensley, S., Kobrick, M., Paller, M., Rodriguez, E., Roth, L., Seal, D., Shaffer, S., Shimada, J., Umland, J., Werner, M., Oskin, M., Burbank, D. and D. Alsdorf. 2007. The Shuttle Radar Topography Mission. Reviews of Geophysics 45, RG2004, DOI:10Đ1029/2005RG000183

Gisler, G. 2008. Tsunami simulations. Annual Review of Fluid Mechanics. Vol. 40, pp. 71-90

Goseberg, N., Stahlmann, A., Schimmels, S. and T. Schlurmann. 2009. Highly-resolved numerical modeling of tsunami run-up and inundation scenario in the city of Padang, West Sumatra. Proc. of the $31^{\text {st }}$ International Conference on Coastal Engineering (ICCE2008), American Society of Civil Engineers (ASCE), pp. 27-40

Goseberg, N. and T. Schlurmann. 2010. Numerical and physical study on tsunami run-up and inundation influenced by macro-roughness elements. Proc. $32^{\text {nd }}$ International Conference on Coastal Engineering (ICCE2010), American Society of Civil Engineers (ASCE), (this issue)

Goto, C. and Ogawa, Y. and Shuto, N. and Imamura, N. 1997. MG-35 - IUGG/IOC Time project: Numerical method of tsunami simulation with the leap-frog scheme, UNESCO/IOC report no. 35

Imamura, F., Bernard, E. N. \& Robinson, A. R. (Eds.). 2009. Tsunamis: Ideas and Observations on Progress in the Study of the Seas. Chap. 10 - Tsunami Modeling: Calculating inundation and hazard maps, Harvard Univ. Press, 15, 321-332 
IOC, IHO and BODC, 2003. Centenary Edition of the GEBCO Digital Atlas, published on CD-ROM on behalf of the Intergovernmental Oceanographic Commission and the International Hydrographic Organization as part of the General Bathymetric Chart of the Oceans, British Oceanographic Data Centre, Liverpool, U.K.

Karvonen, T., Hepojoki, A., Kotola, J. and H.-K. Huhta. 2000. RESCDAM - The use of physical models in dam-break flood analysis, Final report of Helsinki University of Technology

King, D. N. and J. R Goff. 2010. Benefitting from differences in knowledge, practice and belief: Māori oral traditions and natural hazards science. Nat. Hazards Earth Syst. Sci., 10, pp. 1927-1940

Konca, O. A., Avouac, J.-P., Sladen, A., Meltzner, A. J., Sieh, K., Fang, P., Li, Z., Galetzka, J., Genrich, J., Chlieh, M., Natawidjaja, D. H., Bock, Y., Fielding, E. J., Ji, C. and D. V. Helmberger. 2008. Partial rupture of a locked patch of the Sumatra megathrust during the 2007 earthquake sequence. Nature, Vol. 456, Issue 7222, pp. 631-635

Lauterjung, J., Münch, U. and A. Rudloff. 2010. The challenge of installing a tsunami early warning system in the vicinity of the Sunda Arc, Indonesia, Nat. Hazards Earth Syst. Sci., 10, pp. 641-646

Mansinha, L. and D.E. Smylie. 1971. The Displacement Fields of Inclined Faults. Bulletin of the Seismological Society of America, Vol. 61(5): pp. 1433-1440

McCloskey, J., Antonioli, A., Piatanesi, A., Sieh, K., Steacy, S., Nalbant, S. S., Cocco, M., Giunchi, C., Huang, J. D. and P. Dunlop. 2007. Near-field propagation of tsunamis from megathrust earthquakes, Geophysical Research Letters, 34, L14316

McCloskey, J., Antonioli, A., Piatanesi, A., Sieh, K., Steacy, S., Nalbant, S., Cocco, M., Giunchi, C., Huang, J. D. and P. Dunlop. 2008. Tsunami threat in the Indian Ocean from a future megathrust earthquake west of Sumatra. Earth and Planetary Science Letters, Vol. 265, Issues 1-2, pp. 61-81

McCaffrey, R. 2007. The next Great Earthquake, Science, Vol. 315, pp. 1675-1676

Nielsen, O., Roberts, S., Gray, D., McPherson, A. and A. Hitchman. 2005. Hydrodynamic modelling of coastal inundation. In: Zerger, A., Argent, R.M. (Editors), Modelling and Simulation Society of Australia and New Zealand: MODSIM 2005 International Congress on Modelling and Simulation Modelling and Simulation Society of Australia and New Zealand

Okal, E. A. and C. E. Synolakis. 2008. Far-field tsunami hazard from mega-thrust earthquakes in the Indian Ocean. Geophysical Journal International, 172 (3), pp. 995-1015

Schiermeier, Q. 2009. Tsunami Watch. Nature. Vol 462, pp. 968-969, doi:10.1038/462968a

Schlurmann, T., Goseberg, N., Taubenböck, H., Setiadi, N., Lämmel, G., Moder, F., Oczipka, M., Klüpfel, H., Wahl, R., Strunz, G., Birkmann, J., Nagel, K., Siegert, F., Lehmann, F., Dech, S., Gress, A. and R. Klein. 2010. Numerisches Last-Mile Frühwarn- und Evakuierungsinformationssystem. BMBF Abschlussbericht, Förderkennzeichen 03G0666A-H (in German)

Sieh, K., 2006. Sumatran megathrust earthquakes - from science to saving lives. Philosophical Transactions of the Royal Society A, Vol. 364, pp. 1947-1963.

Sieh, K., Natawidjaja, D.H., Meltzner, A.J., Shen, C.-C., Cheng, H., Li, K.-S., Suwargadi, B.W., Galetzka, J., Philibosian, B., R.L. Edwards. 2008. Earthquake supercycles inferred from sea-level changes recorded in the corals of west Sumatra, Science, 322 (5908), pp. 1674-1678.

Spahn, H., Hoppe, M., Vidiarina, H. D., and Usdianto, B.: Experience from three years of local capacity development for tsunami early warning in Indonesia: challenges, lessons and the way ahead, Nat. Hazards Earth Syst. Sci. (NHESS), Vol. 10, pp. 1411-1429

Subarya, C., Chlieh, M., Prawirodirdjo, L., Avouac, J.-P., Bock, Y., Sieh, K., Meltzner, A.J., Natawidjaja, D.H., McCaffrey, R. 2006. Plate-boundary deformation associated with the great Sumatra-Andaman earthquake. Nature, 440 (7080), pp. 46-51.

Synolakis, C. E. and E. Bernard. 2006. Tsunami science before and beyond Boxing Day 2004. Philosophical Transactions of the Royal Society A, Vol. 364, pp. 2231-2265.

Taubenböck, H., Goseberg, N., Setiadi, N., Lämmel, G., Moder, F., Oczipka, M., Klüpfel, H., Wahl, R., Schlurmann, T., Strunz, G., Birkmann, J., Nagel, K., Siegert, F., Lehmann, F., Dech, S., Gress, A. and R. Klein. 2009. Last-Mile preparation to a potential disaster - Interdisciplinary approach towards tsunami early warning and an evacuation information system for the coastal city of Padang, Indonesia. Nat. Hazards Earth Syst. Sci. (NHESS), Vol. 9, pp. 1509-1528

Ward, S. N. and Day, S. 2008. Tsunami balls: A granular approach to tsunami runup and inundation. Communications in Computational Physics, 3(1), pp. 222-249

Zoppou, C. and S. Roberts. 1999. Catastrophic Collapse of Water Supply Reservoirs in Urban Areas. Journal of Hydraulic Engineering, Vol. 125, S. 686-695 